\title{
Nutrient Availability in Bt. Cotton under Drip Fertigation
}

\author{
Jana Harish" ${ }^{*}$ D.D. Pawar, K.D. Kale, R.R. Hasure and S.K. Dingre \\ Department of Irrigation Water Management, Mahatma Phule Krishi Vidyapeeth, \\ Rahuri-413722, Maharashtra, India \\ *Corresponding author
}

\begin{tabular}{|c|c|}
\hline & B S T F \\
\hline & \multirow{5}{*}{$\begin{array}{l}\text { Cotton occupies sizeable area in India including Maharashtra which is progressively } \\
\text { increasing with creation of irrigation amenities. Farmers adopting furrow irrigation causes } \\
\text { percolation, nutrient leaching and volatilization at one end and unproductive loss of ground } \\
\text { or surface water on the other end. Therefore, experiments were conducted during Kharif } \\
\text { season of } 2015-2016 \text { to evaluate nutrient availability in Bt cotton by using drip fertigation } \\
\text { under different phosphorous sources. The experiment consisted of eight treatments and } \\
\text { replicated thrice. Application of } 100 \%(24: 24: 00) \text { fertigation through drip }\left(\mathrm{T}_{1}\right) \text { was } \\
\text { significantly superior over soil application under surface irrigation and registered the } \\
\text { maximum availability of } \mathrm{N}, \mathrm{P} \text { and } \mathrm{K}\left(241.11,37.03 \text { and } 608.81 \mathrm{Kg} \mathrm{ha}^{-1}\right) \text { at } 90 \mathrm{DAS} \\
\text { gradually it was decreasing at harvest stage and it consists } 169.31,19.97 \text { and } 459.81 \mathrm{Kg} \mathrm{N} \text {, } \\
\mathrm{P} \text { and } \mathrm{K} \mathrm{ha}{ }^{-1} \text {. While comparing with surface irrigation treatment }\left(\mathrm{T}_{8}\right) 5.4,24.8 \text { and } 8.9 \% \\
\text { more availability of NPK in application of } 100 \% \text { fertilizer treatment }\left(\mathrm{T}_{1}\right) \text { at } 90 \mathrm{DAS} \\
\text { gradually it was decreasing because of fertigation was adopted up to } 14 \text { weekly splits. }\end{array}$} \\
\hline Keywords & \\
\hline Article Info & \\
\hline & \\
\hline & \\
\hline
\end{tabular}

\section{Introduction}

Cotton enjoys a predominant position among all cash crops in India. Cotton is an important raw material for the Indian textile industry, constituting about $65 \%$ of its requirements. The Indian textile industry occupies a significant place in the country's economy with more than 1500 mills, 4 million handlooms, 1.7 million power looms, and thousands of garments, hosiery, and processing units, providing employment directly or indirectly to around 35 million people (Sankaranarayanan et al., 2011). In India, cotton occupies an area of nearly 7.39 million ha, with a production of 2.38 million metric tons (2002-03), ranking third in the world. However, cotton productivity is very low in India, and its production contribution is only $9 \%$ compared to $22 \%$ in China and $19.4 \%$ in the United States (FAO, 2009). The lint productivity of cotton is $322 \mathrm{~kg} \mathrm{ha}^{-1}$, which is the lowest and far below that of the world average of $627 \mathrm{~kg} \mathrm{ha}^{-1}$ (Shivagaje et al., 2004). With advancement in superior hybrids and production technologies such as a $\mathrm{Bt}$ cotton, cotton cultivation is gaining momentum and there exists potential scope for enhancing its productivity. Bt cotton was first planted in India in 2002, following its success, the area under this crop and the number of farmers who adopted this technology 
increased significantly from year to year. The projection made in India for $2020 \mathrm{AD}$ is around 47.5 million bales of lint to meet the anticipated domestic and export requirement. To fulfill this projected requirement, the cotton production has to be increased by $15 \%$ and it has to come mainly from increased productivity. Current stock of cotton in the country is estimated at 54 lakh bales as against 43 lakh bales during the year 2007-08 (Thimmareddy et al., 2013). There is an encouraging response of farmers towards $\mathrm{Bt}$ cotton cultivation while replacing traditional varieties and hybrids at stroke, just to escape bollworm menace and to achieve potential yield.

But unfortunately, there is no specific blue print regarding agronomic package for $\mathrm{Bt}$ cotton which has a tremendous yield potentiality by virtue of its resistance to bollworm on one hand and having an excellent canopy architecture, which supports huge number of bolls on the other. Fertilizer requirement is the most critical inputs as far as cotton cultivation is concerned as it is a long duration crop in black cotton soils under rainfed and irrigated conditions. Production and productivity increases of Bt cotton can be achieved through enhanced soil fertility. Soil fertility can only be sustained if the nutrients removed from soil are replenished by way of additions (Kairon and Venugopalan, 2000). Supplying the entire quantity of nutrients required through fertilizers may not be possible through traditional method of irrigation. At present, there is a wide gap between the supply and removal nutrients by crops (Tandon and Narayan, 1990). Therefore, an integration of like drip irrigation sources has to be done. Hence, a field study was conducted to find out a suitable fertilizer levels for Bt cotton hybrids which are being well accepted by farmers across the country and more so in black cotton soils of Maharashtra.

\section{Materials and Methods}

The field experiment was conducted at the Research Farm of Inter Faculty Department of Irrigation Water Management, PGI, M.P.K.V., Rahuri (Maharashtra). Climatically the central campus falls in the semi - arid zone with annual rainfall varying from 307 to $619 \mathrm{~mm}$, with an average of $520 \mathrm{~mm}$. The rainfall is erratic and ill distributed in nature. Most of the rainfall is generally received from South West Monsoon in 15-45rainy days. The mean pan evaporation ranges from 2.2 to $7.6 \mathrm{~mm}$ day-1. Agro-climatically the area falls under drought prone area of Maharashtra state facing droughts frequently, especially during last 4 years. The soil of experimental site was uniform and levelled. It was well drained and clay loam in texture. A composite soil sample from $0-30 \mathrm{~cm}$ soil layer was collected prior to sowing and analyzed for physical and chemical properties and also presented in Table 1 and 2 . The source of water for irrigation to experimental plot was a tube well installed on farm with a $5 \mathrm{hp}$ submersible pump. The water was stored in a tank of 30,000 litters capacity and used for irrigation, as and when required.

\section{Experimental details}

The field experiment was laid out with 8 treatments replicated thrice in randomized block design (RBD). Dibbling of cotton was done on 11 June, 2015 using Bt. Cotton cultivar Ajeet (ACH-155) at $0.75-1.50 \times 0.75$ $\mathrm{m}$ spacing. The experiment comprised of $\mathrm{T} 1-$ $100 \%$ fertigation $(24: 24: 00), \quad \mathrm{T} 2-75 \%$ fertigation (24:24:00), T3 - 50\% fertigation (24:24:00), T4 - 75\% fertigation (19:19:19), T5 $-75 \%$ fertigation (12:61:00), T6 - no fertilizer under drip irrigation, T7 - 100\% conventional fertilizer under drip irrigation and T8 $-100 \%$ conventional fertilizers under surface irrigation. Drip irrigation system with pressure compensating inline drippers was laid 
out as per treatments. One lateral per two rows of cotton with lateral-to-lateral spacing of 2.25 $\mathrm{m}$ and emitter-to-emitter spacing as $0.50 \mathrm{~m}$ was used. In drip fertigation, the application of fertilizers was done with the help of power tiller operated HTP pump and a tank, which was connected to each manifold, at the time of fertigation. For fertigation, the water-soluble grades as 24:24:00, 19:19:19 and 12:61:00 were, used as phosphorous sources. In each fertigation treatments remaining Nitrogen and full Potassium was applied through urea (46:00:00) and sulphate of potash (00:00:50). In all fertigation treatments ( $\mathrm{T} 1$ to $\mathrm{T} 5$ ), the fertilizers were applied in recommended (Pawar et al., 2014)14 weekly splits as per schedule given in Table 3 . In conventional fertilization (T7 and T8), urea, single super phosphate and muriate of potash were used as nutrient source.

In case of drip irrigation treatments, the irrigation scheduling was done based on climatologically approach. Irrigation was scheduled on alternate days in all drip irrigated treatments. The quantity of irrigation water was estimated using Allen et al., 1998 In conventional method of irrigation, water was applied based on water holding capacity of soil. In present investigation, $10.29 \mathrm{~cm}$ of water was applied at every $75 \mathrm{~mm}$ CPE (cumulative pan evaporation).

\section{Results and Discussion}

\section{Nitrogen availability in soil}

The nitrogen availability in the root zone was found to be influenced by period and levels of fertilizers (Table 4). The $\mathrm{N}$ availability was increased over the period from sowing in all treatments up to 90 DAS and there after decreased up to the harvesting stage in all the treatments. The decreased $\mathrm{N}$ availability in the soil after 90 DAS may be due to higher uptake of $\mathrm{N}$ by plants at boll formation and boll maturation stage. The level of fertilizer influenced the $\mathrm{N}$ availability in soil up to some extent. The maximum $\mathrm{N}$ availability was observed in treatment $\mathrm{T} 1 \mathrm{(100 \%}$ fertigation through drip irrigation) and was decreased with decreasing fertilizer levels. The lowest value of availability was observed in treatment T6 (DI with no fertigation) at all stages. The nitrogen availability in T1 (100\% fertigation) treatment (209.31 kg ha ${ }^{-1}$ ) was significantly higher over all other treatments at 45 DAS. The $100 \%$ fertigation using water soluble fertilizers rather than the conventional fertilizers was the reason for higher $\mathrm{N}$ availability of T1, T2, T4 and T5. At 90 DAS, treatment $\mathrm{T} 1$ recorded significantly more $\mathrm{N}$ availability i.e., $241.11 \mathrm{~kg} \mathrm{ha}^{-1}$ in soil than all treatments except T2 $\left(237.67 \mathrm{~kg} \mathrm{ha}^{-1}\right)$, T4 (230.67 kg ha ${ }^{-1}$ ) and T5 (229.98 kg ha $\left.{ }^{-1}\right)$. A similar trend was observed at 135 DAS. At harvest, $\mathrm{T} 1$ resulted into maximum $\mathrm{N}$ availability. The treatments T7 and T8, where $\mathrm{N}$ was applied through soil, resulted into less availability in the soil after 90 DAS (when crop required more $\mathrm{N}$ ) compared to fertigation treatments. These treatments might have resulted into a more leaching of fertilizers and in turn would have made less fertilizer available. The sources of fertilizers also resulted in a moderate change in $\mathrm{N}$ availability in the root zone soil of cotton crop at all the stages. The water soluble fertilizers resulted into more availability of $\mathrm{N}$ in soil when $100 \%$ $\mathrm{N}$ was applied through drip in the form of urea and 24:24:00 as compared to conventional fertilizers. It resulted in the increased $\mathrm{N}$ availability in $\mathrm{T} 1$ to the extent of $4.94 \mathrm{~kg} \mathrm{ha}^{-1}$ as compared to $\mathrm{T} 8$ at harvesting. Similar results are also formed by the Jayakumar et al., (2014).

\section{Availability of phosphorus in soil}

The data regarding soil available phosphorus was influenced significantly due to different treatments. 
Table.1 Methods used for determination of physical and chemical properties of the soil

\begin{tabular}{|c|c|c|c|}
\hline Sr. No. & Characteristics & Method & References \\
\hline \multicolumn{4}{|c|}{ A. Physical property } \\
\hline 1. & Textural class & International pipette method & Klute (1986) \\
\hline 2. & Infiltration rate $\left(\mathrm{mm} \mathrm{hr}^{-1}\right)$ & Double ring infiltrometer & Klute (1986) \\
\hline 3. & Bulk density $\left(\mathrm{Mg} \mathrm{m}^{-3}\right)$ & Core sampler method & Black and Hartage (1986) \\
\hline 4. & MWHC (\%) & Perforated brass dish & Keen, (1928) \\
\hline 5. & Field capacity (\%) & Pressure plate apparatus & Richards (1947) \\
\hline 6. & PWP (\%) & Pressure plate apparatus & Dastane (1972) \\
\hline \multicolumn{4}{|c|}{ B. Chemical analysis } \\
\hline 1. & $\mathrm{p}^{\mathrm{H}}$ & Potentiometric & Jackson(1973) \\
\hline 2. & $\mathrm{EC}$ & Conduct metric method & Jackson(1973) \\
\hline 3. & Available $\mathrm{N}\left(\mathrm{Kg} \mathrm{ha}^{-1}\right)$ & Alkaline permanganate method & Subbiah and Ashja (1955) \\
\hline 4. & Available $\mathrm{P}\left(\mathrm{Kg} \mathrm{ha}^{-1}\right)$ & $0.5 \mathrm{M} \mathrm{NaHCO}_{3}(\mathrm{pH} 8.5)$ & Olsen et al., (1954) \\
\hline 5. & Available $\mathrm{K}\left(\mathrm{Kg} \mathrm{ha}^{-1}\right)$ & Flame photometer & Hanway and Heidal (1967) \\
\hline
\end{tabular}

Table.2 Initial characteristics of study area

\begin{tabular}{|c|c|c|}
\hline Sr. No. & Characteristics & Composition \\
\hline $\mathbf{I}$ & \multicolumn{2}{|l|}{ Physical Properties } \\
\hline 1. & Textural Class & Clay Loam \\
\hline 2. & Field Capacity (\%) & 38.62 \\
\hline 3. & Permanent Wilting Point (\%) & 18.20 \\
\hline 4. & Bulk Density $\left(\mathrm{Mg} \mathrm{m}^{-3}\right)$ & 1.26 \\
\hline 5. & Infiltration rate $\left(\mathrm{mm} \mathrm{hr}^{-1}\right)$ & 6.18 \\
\hline 6. & Available soil moisture (\%) & 20.42 \\
\hline II & \multicolumn{2}{|l|}{ Chemical Properties } \\
\hline 1. & $\mathrm{pH}(1: 2.5)$ & 8.12 \\
\hline 2. & $\mathrm{EC}\left(\mathrm{dSm}^{-1}\right)(1: 2.5)$ & 0.26 \\
\hline 3. & Available $\mathrm{N}\left(\mathrm{kg} \mathrm{ha}^{-1}\right)$ & 180.21 \\
\hline 4. & Available P $\left(\mathrm{kg} \mathrm{ha}^{-1}\right)$ & 18.43 \\
\hline 5. & Available K (kg ha $\left.{ }^{-1}\right)$ & 450.67 \\
\hline
\end{tabular}

Table.3 Nutrients to be applied in 14 weekly splits for Bt. cotton crop

\begin{tabular}{|c|c|c|c|c|c|c|}
\hline Days after sowing & \multicolumn{2}{|c|}{ Nitrogen } & \multicolumn{2}{|c|}{ Phosphorous } & \multicolumn{2}{|c|}{ Potash } \\
\cline { 2 - 7 } & $\%$ & $\mathrm{~kg} \mathrm{ha}^{-1}$ & $\%$ & $\mathrm{~kg} \mathrm{ha}^{-1}$ & $\%$ & $\mathrm{~kg} \mathrm{ha}^{-1}$ \\
\hline 1-3 weeks & 30 & 37.5 & 22 & 14.3 & 10 & 6.5 \\
\hline 4-7 weeks & 25 & 31.25 & 40 & 26 & 30 & 19.5 \\
\hline 8-10 weeks & 28 & 35 & 30 & 19.5 & 22 & 14.3 \\
\hline 11-14 weeks & 17 & 21.25 & 8 & 5.2 & 38 & 24.7 \\
\hline Total & 100 & 125 & 100 & 65 & 100 & 65 \\
\hline
\end{tabular}


Table.4 Periodical nitrogen availability in soil of Bt. cotton

\begin{tabular}{|c|}
\hline Treatment \\
\hline $\mathrm{T}_{1}$-DI with $100 \%$ WSF $(24: 24: 00)$ \\
\hline $\mathrm{T}_{2}$-DI with $75 \%$ WSF $(24: 24: 00)$ \\
\hline $\mathrm{T}_{3}$-DI with $50 \%$ WSF $(24: 24: 00)$ \\
\hline $\mathrm{T}_{4}$-DI with $75 \%$ WSF $(19: 19: 19)$ \\
\hline $\mathrm{T}_{5}$-DI with $75 \%$ WSF (12:61:00) \\
\hline $\mathrm{T}_{6}$-DI with no fertigation \\
\hline T 7 -DI with $100 \% \mathrm{CF}$ \\
\hline $\mathrm{T}_{8}$-SI with $100 \% \mathrm{CF}$ \\
\hline $\mathbf{S E}( \pm)$ \\
\hline CD@5\% \\
\hline
\end{tabular}

\begin{tabular}{|c|c|c|c|}
\hline \multicolumn{4}{|c|}{ Nitrogen availability $\left(\mathrm{kg} \mathrm{ha}^{-1}\right)$} \\
\hline 45 DAS & 90 DAS & 135 DAS & At harvest \\
\hline 209.31 & 241.11 & 238.66 & 169.31 \\
\hline 196.38 & 237.67 & 227.51 & 164.60 \\
\hline 184.40 & 206.37 & 195.36 & 153.46 \\
\hline 195.82 & 230.67 & 221.43 & 162.60 \\
\hline 195.53 & 229.98 & 220.91 & 161.93 \\
\hline 177.68 & 176.56 & 169.97 & 155.47 \\
\hline 203.38 & 229.34 & 203.31 & 165.06 \\
\hline 201.78 & 228.67 & 189.79 & 164.37 \\
\hline 1.21 & 3.86 & 6.29 & 1.90 \\
\hline 3.63 & 11.56 & 18.85 & 5.71 \\
\hline
\end{tabular}

Table.5 Periodical phosphorus availability in soil of Bt. cotton

\begin{tabular}{|c|}
\hline \multicolumn{1}{|c|}{ Treatment } \\
\hline $\mathrm{T}_{1}$-DI with 100\% WSF (24:24:00) \\
\hline $\mathrm{T}_{2}$-DI with 75\% WSF $(24: 24: 00)$ \\
\hline $\mathrm{T}_{3}$-DI with 50\% WSF $(24: 24: 00)$ \\
\hline $\mathrm{T}_{4}$-DI with 75\% WSF (19:19:19) \\
\hline $\mathrm{T}_{5}$-DI with 75\% WSF (12:61:00) \\
\hline $\mathrm{T}_{6}$-DI with no fertigation \\
\hline $\mathrm{T}_{7}$-DI with 100\% CF \\
\hline $\mathrm{T}_{8}$-SI with 100\% CF \\
\hline SE $( \pm)$ \\
\hline CD @5\% \\
\hline
\end{tabular}

\begin{tabular}{|c|c|c|c|}
\hline \multicolumn{4}{|c|}{ Phosphorus availability $\left(\mathrm{kg} \mathrm{ha}^{-1}\right)$} \\
\hline 45 DAS & 90 DAS & 135 DAS & At harvest \\
\hline 33.14 & 37.03 & 28.65 & 19.97 \\
\hline 32.09 & 36.52 & 26.40 & 18.96 \\
\hline 25.26 & 28.85 & 20.04 & 16.03 \\
\hline 31.26 & 34.69 & 25.93 & 17.87 \\
\hline 30.79 & 32.87 & 23.47 & 17.36 \\
\hline 17.76 & 17.14 & 16.36 & 14.26 \\
\hline 29.18 & 30.35 & 19.96 & 16.04 \\
\hline 28.10 & 29.65 & 19.21 & 15.84 \\
\hline 0.83 & 1.05 & 0.80 & 0.26 \\
\hline 2.49 & 3.15 & 2.41 & 0.79 \\
\hline
\end{tabular}

Table.6 Periodical potassium availability in soil of Bt. cotton

\begin{tabular}{|c|} 
Treatment \\
\hline $\mathrm{T}_{1}$-DI with $100 \%$ WSF 24:24:00) \\
\hline $\mathrm{T}_{2}$-DI with $75 \%$ WSF $(24: 24: 00)$ \\
\hline $\mathrm{T}_{3}$-DI with $50 \%$ WSF $(24: 24: 00)$ \\
\hline $\mathrm{T}_{4}$-DI with $75 \%$ WSF $(19: 19: 19)$ \\
\hline $\mathrm{T}_{5}$-DI with $75 \%$ WSF $(12: 61: 00)$ \\
\hline $\mathrm{T}_{6}$-DI with no fertigation \\
\hline $\mathrm{T}_{7}$-DI with $100 \%$ CF \\
\hline $\mathrm{T}_{8}$-SI with 100\% CF \\
\hline SE $( \pm)$ \\
\hline CD @5\% \\
\hline
\end{tabular}

\begin{tabular}{|c|c|c|c|}
\hline \multicolumn{4}{|c|}{ Potassium availability $\left(\mathrm{kg} \mathrm{ha}^{-1}\right)$} \\
\hline 45 DAS & 90 DAS & 135 DAS & At harvest \\
\hline 575.24 & 608.81 & 591.22 & 459.81 \\
\hline 565.59 & 591.46 & 581.55 & 453.73 \\
\hline 529.82 & 568.74 & 550.55 & 440.16 \\
\hline 558.62 & 587.41 & 578.36 & 452.16 \\
\hline 540.59 & 580.72 & 577.54 & 450.16 \\
\hline 450.25 & 449.44 & 444.24 & 403.55 \\
\hline 527.21 & 563.44 & 549.24 & 438.16 \\
\hline 523.80 & 558.55 & 540.24 & 432.86 \\
\hline 1.79 & 2.62 & 2.97 & 2.95 \\
\hline 5.37 & 7.86 & 8.90 & 8.85 \\
\hline
\end{tabular}


The average phosphorus availability in the root zone was found to be influenced by period, method of fertilization and levels of fertilizers (Table 5). The availability of $\mathrm{P}$ in the soil depends upon their solubility, moisture and its variation. The $\mathrm{P}$ availability was increased with the period from sowing up to 90 DAS and afterwards significantly decreased up to the harvesting stage in all the treatments. The decreased $P$ availability in the soil after 90 DAS may be due to higher uptake of $\mathrm{P}$ by plants in square formation, boll formation and boll maturation stage. The levels of fertilizer also influenced the $P$ availability in soil up to some extent. The maximum $\mathrm{P}$ availability was observed in treatment $\mathrm{T} 1$ (100\% fertigation) and was decreased with decreasing fertilizer levels. The lowest value of availability was observed in treatment T6 (DI with no fertigation) at all stages.

There was a significant difference in phosphorus availability at 45 DAS and maximum phosphorus availability was observed in the $\mathrm{T} 1 \quad(100 \%$ fertigation) as $33.14 \mathrm{~kg} \mathrm{ha}^{-1}$. However, it was at par with $\mathrm{T} 2$ (32.09 $\left.\mathrm{kg} \mathrm{ha} \mathrm{ha}^{-1}\right), \quad \mathrm{T} 4\left(31.26 \mathrm{~kg} \mathrm{ha}^{-1}\right)$ and $\mathrm{T} 5\left(30.79 \mathrm{~kg} \mathrm{ha}^{-1}\right)$ The maximum $\mathrm{P}$ availability in T1 might be due to application of $100 \%$ fertigation through water soluble fertilizers rather than conventional fertilization. At 90 DAS, treatment $\mathrm{T} 1$ recorded significantly more $\mathrm{P}$ availability $\left(37.03 \mathrm{~kg} \mathrm{ha}^{-1}\right)$ in soil over all treatments except T2 $\left(36.52 \mathrm{~kg} \mathrm{ha}^{-1}\right)$ and T4 (34.69 kg ha ${ }^{-1}$ ). At 135 DAS, P availability in treatment $\mathrm{T} 1$ was significantly maximum than all other treatments except T2.At harvest, $\mathrm{P}$ availability in treatment $\mathrm{T} 1$ was significantly maximum than all other treatments. The treatment $\mathrm{T} 7$ and $\mathrm{T} 8$ where all the $\mathrm{P}$ was applied through soil resulted in less availability in the soil after 90 DAS compared to fertigation treatments. The results close conformation with Bhakare et al., (2015) and Gundlur et al., (2013).

\section{Availability of potassium in soil}

The effect of different fertigation and irrigation treatments on Potassium availability in soil was presented in Table 6. The $\mathrm{K}$ availability was increased from sowing till 90 DAS and decreased up to the harvesting stage in all the treatments. The decreased $\mathrm{K}$ availability in the soil after 90 DAS may be due to higher uptake of $\mathrm{K}$ by plants at flower initiation, boll formation and boll maturation stage. The level of fertilizer had influenced the $\mathrm{K}$ availability in soil up to some extent. The maximum availability of $\mathrm{K}$ was observed in treatment $\mathrm{T} 1$ (100\% fertigation) and was decreased with decreasing fertilizer levels. The lowest value of available $\mathrm{K}$ was observed in treatment T6 (DI with no fertilizer) at all stages. The treatment differences due to levels of fertilizer were significant at all growth stages.

At 45 DAS T1 (100\% fertigation) showed maximum potassium availability $(575.11 \mathrm{~kg}$ $\mathrm{ha}^{-1}$ ) in the soil compared to other treatments followed by $\mathrm{T} 2\left(565.59 \mathrm{~kg} \mathrm{ha}{ }^{-1}\right)$. In $\mathrm{T} 1$ availability of $\mathrm{K}$ might be more due to use of water soluble fertilizers rather than conventional fertilizers. At harvest, T1 recorded significantly more $\mathrm{K}$ availability $\left(459.81 \mathrm{~kg} \mathrm{ha}^{-1}\right)$ in soil over all other treatments except T2 (453.73 $\left.\mathrm{kg} \mathrm{ha}^{-1}\right)$ and T4 $\left(452.16 \mathrm{~kg} \mathrm{ha}^{-1}\right)$ The method of fertilizer application also resulted in a moderate change in $\mathrm{K}$ availability in the root zone soil of cotton crop at all the stages. The fertigation treatments T1 used 100\% WSF in 14 splits as per crop growth stages as compared to conventional fertilization. At harvest, the $\mathrm{K}$ availability in T1 was up to the extent of $56.26 \mathrm{~kg} \mathrm{ha}^{-1}$ more as compared to T6 (DI with no fertgation); and however, when it was compared with $\mathrm{T} 7$ where $\mathrm{K}$ was applied through soil, the availability was increased to the extent of $21.65 \mathrm{~kg} \mathrm{ha}^{-1}$. As optimum quantum of water was available just beneath 
the in-drip method of irrigation, there was a corresponding increase in $\mathrm{K}$ availability in the soil. It has been inferred a direct association between $\mathrm{K}$ availability and presence of irrigation water. Similar results are also found by the Bhakare et al., (2015) and are close line with the present study.

\section{References}

Allen, R. G., Pereira, L. S., Raes, D., Smith, M., Crop evapotranspiration. FAO irrigation and drainage Paper No.56.Rome., 1998.

Bhakare, B. D., Kawade V.Y. and Tuwar, S.S., Effect of fertigation on soil nutrients, chemical properties and yield of $\mathrm{Bt}$. Cotton. BIOINFOLET 12 (2 B): 479 - 483, 2015.

Black, G. H. and Hartge, K. H. 1986. Bulk density In: Klute A. (Ed.): Methods of soil analysis. Am. Soc. Agron. 2nd Ed, Agron. No. 9 (Part I): $363-375$.

Dastane, N. G., A practical manual for water use research in Agriculture Nava Bharat Prakashan, Pune-2 (India). 1972, pp.120.

FAO, FAO Statistical Database. Food and Agriculture Organization of the United Nations, 2009.www.http://faostat.fao.org.

Gundlur S. S., Rajkumara, S., Neelakanth J. K., Aashoka P. and Khot., Water and nutrient requirement of $\mathrm{Bt}$ cotton under vertisols of Malaprabha command. Karnataka J. Agric. Sci., 26(3): 368-371, 2013.

Hanway, J. and Haidal, H. Soil analysis method as used inIOWA State College Soil Testing Laboratory. IOWA, 57:1-31, 1967.

Jackson, M. L., Plant Chemical Analysis, Prentice Hall of India Pvt. Ltd., New Delhi. 1973, pp. 573.

Jayakumar, M., Surendran $U$ and Manickasundaram, P., Drip fertigation effects on yield, nutrient uptake and soil fertility of $\mathrm{Bt}$ Cotton in semiarid tropics. International
Journal of Plant Production 8 (3), July 2014, ISSN: 1735-6814, 2014.

Kairon, M. S. and Venugopalan, M. V., Nutrient management in cotton and cotton- based cropping systems. Ferti. News., 45(4):51-56., 2000.

Klute, A. Methods of Soil Analysis. Part IPhysical and Mineralogical Methods. Second Edition. 1986.

Olsen, R. A., Estimation of available phosphorous by extraction with sodium carbonate. U.S.D.A. Civ. 939, 1954.

Pawar, D.D., Dingre, S.K. and Surve, U.S., Split application ofnutrients through fertigation in Bt cotton. J. Cotton Res. Dev.28 (2) 238-242, 2014.

Richards, L.A. Pressure membrane apparatus construction and use. Agril. Engg. 28:45-54, 1947.

Sankaranarayanan, K., Nalayini, P., Sabesh, M., Usha Rani, S., Nachane, R.P., Gopalakrishnan, N., Low Cost Drip-Cost Effective and Precision Irrigation Tool in $\mathrm{Bt}$ Cotton. Technical Bulletin No.1/2011, Published by Central Institute for Cotton Research, Regional Station, Coimbatore- 641 003, 2011.

Shivagaje, A., Kasture, M., Yadav, D., Pandharikar, N., Mathankar, M., Cotton scenario in India, Curr. Sci. 87, 15-26, 2004.

Subbiah, B. V. and Asija, G. L., A rapid procedure for the determination of available nitrogen in soils. Cur. Sci. 25: 259-260., 1955.

Tandon, H. L. S. and Narayan, P., Fertilizers in Indianagriculture: Past, present and future (1950-2000), FDCO, NewDelhi, India, 1990, pp. 160.

Thimmareddy, K., Desai, B.K and Innodakumar, S.N., Seed cotton yield, uptake of NPK and Economics of Bt. Cotton (Gosssypium hirsutum L.) as influenced by different Biofertilizers and in- situ green manuring under irrigation. Trends in Biosciences 6(6):838-841, 2013.

\section{How to cite this article:}

Jana Harish, D.D. Pawar, K.D. Kale, R.R. Hasure and S.K. Dingre. 2018. Nutrient Availability in Bt. Cotton under Drip Fertigation. Int.J.Curr.Microbiol.App.Sci. 7(04): 3373-3379.

doi: https://doi.org/10.20546/ijcmas.2018.704.381 